\title{
Temperature effects on the heterotrophic bacteria, heterotrophic nanoflagellates, and microbial top predators of the NW Mediterranean
}

\author{
Evaristo Vázquez-Domínguez ${ }^{1, *}$, Dolors Vaqué2 ${ }^{\text {, Josep M. Gasol }}{ }^{2}$ \\ ${ }^{1}$ Centro Oceanográfico de Gijón/Xixón (Instituto Español de Oceanografía), Avenida Príncipe de Asturias 70, \\ Gijón/Xixón (Asturies) 33212, Spain \\ ${ }^{2}$ Institut de Ciències del Mar, CSIC, Passeig Marítim de la Barceloneta, 37-49, Barcelona (Catalonia) 08003, Spain
}

\begin{abstract}
Prokaryotes and protists are important players in the carbon biogeochemistry of marine ecosystems, and temperature is one of the physical factors most influential in the metabolism and composition of plankton communities. Small changes in temperature can change the flow of carbon and the community structure of planktonic ecosystems, and climatological models predict a rise in temperature of 2 to $5^{\circ} \mathrm{C}$ toward the end of the century in the NW Mediterranean. Laboratory culture experiments have shown that warming can increase the transfer of carbon between bacteria and protists and alter the community composition of microbial top predators (i.e. ciliates and dinoflagellates) by increasing the abundance of bacterivores and producing the extinction of herbivores. Here, we tested whether a small rise in temperature would produce these effects in the coastal Mediterranean. Between March 2003 and February 2004, we established 12 microcosm experiments with water from the Bay of Blanes. The samples were incubated for $48 \mathrm{~h}$ at ambient and warmer temperatures $\left(\sim 2.7^{\circ} \mathrm{C}\right.$ higher than in situ values), and the net and gross growth rates of bacteria and heterotrophic nanoflagellates (HNF) were measured using unfiltered and $0.8 \mu \mathrm{m}$ filtered treatments. Warming increased the rates of bacterial gross production and bacterial losses to grazing with a clear seasonality; the largest increments in the rates were observed during the cooler months of the year. Warming did not change the net growth rates of dinoflagellates. It decreased the net production of HNF and the net growth rates of ciliates but did not promote the extinction of herbivorous protists. Temperature changed the microbial food web function in NW Mediterranean waters, with small alterations in the community composition of microbial top predators.
\end{abstract}

KEY WORDS: Temperature $\cdot$ Carbon cycle $\cdot$ Function and structure $\cdot$ Microbial food web $\cdot$ NW Mediterranean

Resale or republication not permitted without written consent of the publisher

\section{INTRODUCTION}

Most organic carbon in the sea is found as dissolved organic carbon (Siegenthaler \& Sarmiento 1993), and the degradation and transfer of this dissolved organic carbon to higher trophic levels is mediated by heterotrophic bacteria and protists (Azam et al. 1983). Heterotrophic bacteria transform the dissolved organic carbon into biomass by anabolic processes and, while a large fraction (>50\%) of this dissolved organic carbon is recycled back to the ecosystem as $\mathrm{CO}_{2}$ through respiration processes (Ducklow et al. 1986), bacteria accumulate some of it as biomass. Subsequently, bacteria may be lysed by viruses (Fuhrman 1999) or preyed upon by phagotrophic protists (nano- and microplankton). All of these complex trophic interactions involving pelagic microbes are collectively known as the microbial food web (Azam et al. 1983, Sherr \& Sherr 1988). 
Oligotrophic planktonic ecosystems are responsible for nearly $22 \%$ of net primary production in the oceans (Field et al. 1998). Their carbon biomass is dominated by planktonic microbes (Gasol et al. 1997), and $>40 \%$ of their secondary bacterial production is consumed by protists (Vázquez-Domínguez et al. 2005). In these ecosystems, nanoflagellates are often top-down controlled by microzooplankton, such as ciliates and dinoflagellates (Hansen 1991, Verity 1991), which are more important than mesozooplankton as consumers of the lower trophic levels (Calbet \& Landry 2004). In oligotrophic conditions, the growth efficiencies of heterotrophic bacteria and protists are $<30 \%$ (Straile 1997, del Giorgio \& Cole 1998), and only a small amount of the primary production of such ecosystems reaches the higher trophic levels. Thus, to understand the carbon cycling of oligotrophic marine ecosystems, we need to understand the transfer of carbon between bacteria, nanoflagellates and the microbial top predators (i.e. ciliates and dinoflagellates).

Sea surface temperatures in the Bay of Blanes (NW Mediterranean) can vary by $\sim 10^{\circ} \mathrm{C}$ over the usual annual seasonal cycle (Alonso-Sáez et al. 2008), and additional sources of variability may change the sea surface temperature of coastal ecosystems by several degrees Celsius in shorter periods of time, such as during extreme heat waves or in the vicinity of the thermal effluents of power stations (Choi et al. 2002). In addition, global sea surface temperatures have been increasing at rates near $0.01^{\circ} \mathrm{C}^{-1}$ since the 1860s (Levitus et al. 2000, Vargas-Yañez et al. 2005, Mackenzie \& Schiedek 2007), and some climatic models predict an increase in atmospheric temperatures ranging between 2.5 and $5^{\circ} \mathrm{C}$ in the Mediterranean region by the end of the century (Christensen et al. 2007). All of these temperature changes may affect the function and the structure of marine ecosystems (Edwards \& Richardson 2004, Wiltshire et al. 2008, Li et al. 2009), and thus they may influence the transfer of carbon within, and community composition of, the microbial food web.

Production $(P)$ and respiration $(R)$ are metabolic processes affected by temperature (Brown 2004); its effect on $P$ and $R$ rates has been shown in both heterotrophic bacteria (Shiah \& Ducklow 1994, Morán et al. 2006, Vázquez-Domínguez et al. 2007) and protists (Rose et al. 2008, 2009). Temperature can also decrease the ratio between primary production and bacterial secondary production (Hoppe et al. 2008), as was observed in mesocosms deployed in Kiel Fjord, where warming increased the recycling of dissolved organic matter (Wohlers et al. 2009). Thus, small changes in temperature can modify the growth efficiencies $(\mathrm{GE})$ of microorganisms $(\mathrm{GE}=P /[P+R])$ and the amount of microbial production that can reach higher trophic levels. Some studies on the effect of temperature on the GE of heterotrophic bacteria show contrasting results: positive (Wohlers et al. 2009), negative (Rivkin \& Legendre 2001) or a lack of effect (Vázquez-Domínguez et al. 2007, Rose et al. 2008). However, there are few studies inspecting the effects of temperature on the transfer of carbon between heterotrophic bacteria and protists, at least in natural microbial communities. Those available show a positive effect of temperature on bacterial grazing rates (Marrasé et al. 1992, Rose \& Caron 2007, Rose et al. 2009).

Temperature may also influence the microplankton community structure of marine ecosystems. In a short time (4 mo), warming produced changes in the species succession and the diversity of the ciliate community in mesocosms deployed in Kiel Bight (Baltic Sea), with an increase in Strombidium and Strobilidium species (Aberle et al. 2007). Similarly, warming increased the abundance of ciliates and decreased the development time of copepods in mesocosms deployed in the Thau Lagoon (Vidussi et al. 2011). Over longer periods of time (within the last $100 \mathrm{yr}$ ), warmer sea surface temperatures changed the community composition of the Ceratium genus in Villefranche Bay due to the disappearance of some stenotherm species (Tunin-Ley et al. 2009). Laboratory experiments have shown that a small increase in temperature per generation time $\left(0.1\right.$ to $\left.0.2^{\circ} \mathrm{C}\right)$ may increase the risk of extinction of herbivorous protists, and microbial communities may become dominated by bacterivores (Petchey et al. 1999). Thus, there is a general consensus that temperature may influence microbial community structure and that this influence may be particularly important for the microplankton top predators (i.e. ciliates and dinoflagellates).

Different approaches can be used to study the effect of warming on the function and community structure of microorganisms in aquatic systems, but perturbation experiments remain one of the most powerful tools (Boyd et al. 2010). Most studies have been performed either with 'model' laboratory communities under nutrient replete conditions or with microbial communities inside mesocosms filled with eutrophic waters. However, much less is known about the effect of warming on the microbial food webs of oligotrophic ecosystems (Vaqué et al. 2009, Sarmento et al. 2010). Aiming to increase our knowledge, 12 microcosm experiments were established during 1 yr in the Bay of Blanes (NW Mediterranean), a well-characterized coastal oligotrophic ecosystem 
(e.g. Alonso-Sáez et al. 2008). The experiments were designed to determine whether temperature (1) affects the growth rates and transfer of carbon among heterotrophic bacteria, nanoflagellates and microzooplankton and (2) produces changes in the community structure of the larger phagotrophic protists (i.e. dinoflagellates and ciliates).

\section{MATERIALS AND METHODS}

\section{Experimental set-up}

Experiments were established monthly in 2003 and 2004 with water from the Blanes Bay Microbial Observatory $\left(41^{\circ} 39^{\prime} \mathrm{N}, 2^{\circ} 48^{\prime} \mathrm{E}\right)$, NW Mediterranean. The in situ water temperature was measured with a calibrated mercury thermometer. Samples of $50 \mathrm{l}$ were collected from $\sim 0.5 \mathrm{n}$ miles offshore, and they were immediately pre-screened with a $200 \mu \mathrm{m}$ Nylon net to remove mesozooplankton. Even though this procedure filtered out adult copepods, some nauplii remained in the samples. Upon transportation to the laboratory ( $1 \mathrm{~h})$, one half of the water (25 l) was left in the dark free from disturbance, and the other half was immediately filtered through a $0.8 \mu \mathrm{m}$ filter (47 mm AAWP filter, Millipore) with a peristaltic pump (1.6 MM-WT head, Watson-Marlow). Filtration was performed at low speed ( 100 rpm) to avoid high pressure and the destruction of protists in the samples. Filtration took between 4 to $5 \mathrm{~h}$ and retained nearly $50 \%$ of heterotrophic bacteria and $99 \%$ of eukaryotes and cyanobacteria. The $0.8 \mu \mathrm{m}$ fraction was treated as a 'control' without predators and was used to estimate the net growth rates of bacteria and the grazing rates of heterotrophic protists on the bacterioplankton community (see section 'Heterotrophic bacteria'). Aliquots of $8 \mathrm{l}$ of each fraction $(<0.8 \mu \mathrm{m}$ and $<200 \mu \mathrm{m}$ ) were distributed into 8 acid-clean polyethylene containers, with 21 per container. Two containers with water of each fraction were placed inside each of 2 isothermal walk-in chambers. One chamber was set at in situ seawater temperature ('ambient' chamber), and the other was set at temperatures that were on average $2.7^{\circ} \mathrm{C}$ above in situ values ('warmer' chamber). The temperatures inside the chambers were checked several times during the incubations by measuring the temperature in the samples with a precision digital thermometer $\left( \pm 0.1^{\circ} \mathrm{C}\right)$. As the present study focused on heterotrophic microorganisms, the chambers were maintained under dark conditions. Experiments lasted for 48 h, after which we measured the variables described below.

\section{Heterotrophic bacteria}

The abundance of heterotrophic bacteria was determined from each sample at Time 0 and from the replicated polyethylene containers at 24 and $48 \mathrm{~h}$. Samples of $1.2 \mathrm{ml}$ were preserved with $1 \%$ paraformaldehyde and $0.05 \%$ glutaraldehyde (final concentration), frozen in liquid nitrogen and stored at $-20^{\circ} \mathrm{C}$. Before analysis, the samples were thawed and stained for 10 to $15 \mathrm{~min}$ with $2.5 \mu \mathrm{M}$ of Syto13 (final concentration). The samples were run through a flow cytometer (FACSCalibur, Becton-Dickinson), at $\sim 12 \mu \mathrm{l} \mathrm{min} \mathrm{min}^{-1}$ and until >100000 events were acquired in log mode. In each sample, yellow-green latex beads were added (0.92 $\mu \mathrm{m}$, Polysciences) as internal standards. Bacteria were detected by their signature in a plot of side scatter vs. green fluorescence (del Giorgio et al. 1996), and concentration in the samples was obtained by weighing the initial and final volume of sample at the start and the end of each run. Average fluorescence of the bacterial population, normalized to that of the beads, was converted to bacterial size (Gasol \& del Giorgio 2000), and bacterial sizes were converted to cellular biomass by using the carbon to volume relationship: pg $\mathrm{C} \mathrm{cell}^{-1}=0.12\left(\mu \mathrm{m}^{3} \mathrm{cell}^{-1}\right)^{0.7}$ (Norland 1993).

Bacterial growth rates $(\mu)$ were estimated from the increase in bacterial biomass in each treatment for 2 periods of time ( 0 to 24 and 0 to $48 \mathrm{~h}$ ) assuming an exponential model: $\mu=\ln \left(N / N_{0}\right) T$, where $T$ is the length of incubation in days, $N_{0}$ is bacterial abundance at the start of incubation, and $N$ is bacterial abundance at the end of incubation. Gross growth rate was measured in the $0.8 \mu \mathrm{m}$ fraction $\left(\mu_{0.8}\right)$, and the net growth rate was measured in the $200 \mu \mathrm{m}$ fraction $\left(\mu_{200}\right)$.

Rates of bacterial production (BP) were estimated as the product between growth rate obtained in the 2 periods of time ( 0 to 24 and 0 to $48 \mathrm{~h}$ ) and initial biomass $\left(\mathrm{BM}_{0}\right)$ in the samples $\left(\mathrm{BP}=\mu \times \mathrm{BM}_{0}\right)$.

Loss rates of heterotrophic bacteria due to predation by protists $(g)$ were estimated for 2 periods of time ( 0 to 24 and 0 to $48 \mathrm{~h}$ ) as the difference between gross growth rate and net growth rate $\left(g=\mu_{0.8}-\mu_{200}\right)$ assuming that the $<0.8 \mu \mathrm{m}$ fraction had no predators. Bacterial biomass lost to grazers $(G)$ was estimated from the loss rates of heterotrophic bacteria and the initial biomass in the samples as $G=g \times \mathrm{BM}_{0}$.

\section{Heterotrophic nanoflagellates}

The abundance of heterotrophic nanoflagellates was determined from each sample at Time 0 and 
from the replicated polyethylene containers at 24 and $48 \mathrm{~h}$. Between 20 to $40 \mathrm{ml}$ of preserved samples (glutaraldehyde, $1 \%$ final concentration) were stained with 4'-6-diamidino-2-phenylindole (Porter \& Feig 1980) at $5 \mu \mathrm{g} \mathrm{ml}^{-1}$ (final concentration) as described by Sieracki et al. (1985). Nanoflagellates were collected onto $0.6 \mu \mathrm{m}$ black polycarbonate filters and observed by epifluorescence microscopy under ultraviolet excitation (Olympus BX40, 1000×). Heterotrophic nanoflagellates presented a bright blue fluorescence, while autotrophic nanoflagellates had a red-orange fluorescence. At least 20 random fields or 30 cells were counted in each filter. Colorless nanoflagellates were assumed to be heterotrophic and pigmented flagellates to be autotrophic. Net growth rates of heterotrophic nanoflagellates were estimated with an exponential model: $\mu=1 / T \times \ln \left(N / N_{0}\right)$. The cellular volume of heterotrophic nanoflagellates was estimated by measuring the axes of each cell with a micrometer eyepiece and assuming ellipsoidal or spherical geometry. From these volumes, the carbon content per heterotrophic nanoflagellate was obtained as pg $\mathrm{C}$ cell $^{-1}=0.22 \times$ cell volume in $\mu^{3}$ (Børsheim \& Bratbak 1987). Biomass was estimated as the product of abundance and average carbon content per cell, and production as the product of net growth rate and initial biomass.

\section{Microplankton top predators}

Ciliates and dinoflagellates were determined at Time 0 and $48 \mathrm{~h}$. Samples were preserved with acidic Lugol's solution (2\% final concentration), and ciliates and dinoflagellates were examined in $100 \mathrm{ml}$ samples that were settled for $48 \mathrm{~h}$ before enumeration. Ciliates and dinoflagellates were counted using an inverted microscope (Nikon) at $200 \times$ or $400 \times$ magnification. A single sample was counted in the case of the in situ population, while 2 replicates (1 per sample at each temperature) were counted in the ambient and warmer conditions. At least half of the sedimentation chamber was counted for dinoflagellates, as small dinoflagellates were very abundant, while for ciliates the entire chamber was screened. Ciliates were identified to genus following Lynn \& Small (2002). Taxa included some genera considered to be heterotrophs and several mixotrophs. Ciliates were grouped into Protostomatea (Balanion sp, Tiarina sp. and Urotrichia sp.), Oligotrichia (Halteria sp., Strombidium sp., Laboea sp. and Tontonia sp.), Choreotrichia, both naked (Strobilidium sp. and
Strombidinopsis sp.) and loricated (tintinnids), Haptoria (Mesodinium sp. and Askenasia sp.), Нypotrichia (Euplotes sp.), and, when we were unable to determine the genera, as 'unknown ciliates'. Major and minor axes of ciliates and dinoflagellates were measured with a calibrated image analysis system, a television screen and a digital camera (Marlin, Allied Vision Technologies) attached to the inverted microscope. Cellular volume was estimated by classical geometry. The average ciliate cell volume for each group was converted to carbon equivalents by using the experimentally derived factor for marine

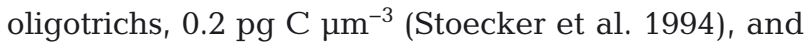
tintinnids, $0.053 \mathrm{pg} \mathrm{C} \mathrm{mm}^{-3}$ (Verity \& Langdon 1984). Dinoflagellates were divided into 4 different categories: Ceratium sp., Gymnodinium sp., Prorocentrum sp. that are $>20 \mu \mathrm{m}$ of length, and 'small dinoflagellates' that have a conspicuous cingulum and are between 10 and $15 \mu \mathrm{m}$ of length. The 3 former groups showed the characteristic features of these genera, common in NW Mediterranean waters (Gómez 2003), and their average cell volume was converted to carbon equivalents by using the carbon to volume relationship of pg $\mathrm{C}$ cell $^{-1}=0.76 \times$ dinoflagellate cellular volume v.819 $^{0.76}$ (Menden-Deuer \& Lessard 2000). The smallest dinoflagellates were assumed to have a diameter of $5 \mu \mathrm{m}$ and thus a biomass of $128 \mathrm{pg} \mathrm{C}$ cell ${ }^{-1}$. Growth rates of ciliates and dinoflagellates were estimated as described for heterotrophic nanoflagellates. Unfortunately, the volume of dinoflagellates was only measured during May, June, July, and September.

The taxonomic richness of microplankton top predators, including small dinoflagellates, was estimated as the total number of taxa present in the samples. The diversity of microplankton top predators was calculated in 2 different ways (Danovaro et al. 2004): (1) the Margalef index of diversity $(D)$, estimated as $D=$ $(\mathrm{TR}-1) / \log N$, where TR is the taxon richness, and $N$ is the abundance of individuals, and (2) the Shannon index of diversity $\left(H^{\prime}\right)=-\sum p_{i} \log _{2}\left(p_{i}\right)$, where $p_{i}=n_{i} / N_{\text {, }}$ and $n_{i}=$ is the number of individuals of taxon $i$. The evenness of the samples was estimated as the modified Hill's numbers: $F=\left(N_{2}-1\right) /\left(N_{1}-1\right)$, where $N_{1}=$ $\exp \left[-\sum p_{i} \ln \left(p_{i}\right)\right]$ and $N_{2}=1 / \sum p_{i}^{2}$ (Alatalo 1981). Such indices were chosen over other diversity indices because the Margalef index is easy to estimate (Marrugan 2004), the Shannon index is often used in aquatic ecosystem studies (e.g. Danovaro et al. 2004, Aberle et al. 2007), and the modified Hills number is one of the better indexes to estimate evenness when the species diversity in the samples is low (Alatalo 1981). 
Data analyses comparing ambient and warmer conditions were performed by establishing monthly averages of each variable and each treatment and by comparing the values at these conditions with paired $t$-tests. Finally, $Q_{10}$ values were estimated as (variable in the warmer conditions/variable at ambient conditions) ${ }^{10 /(w a r m-a m b i e n t ~ t e m p e r a t u r e) ~(S h e r r ~ \& ~ S h e r r ~}$ 1996), and the errors were estimated by standard propagation of errors.

\section{RESULTS}

Between March 2003 and February 2004, the water temperature in the Bay of Blanes varied between $12.5^{\circ} \mathrm{C}$ in February and $25^{\circ} \mathrm{C}$ in July, which offers a relatively large temperature shift (Fig. 1A). Inside the isothermal chambers, the average temperature varied between 12.8 and $25^{\circ} \mathrm{C}$ in the chamber at ambient temperature and between 15.5 and $27.5^{\circ} \mathrm{C}$ in the warmer chamber. The average $( \pm 1 \mathrm{SE})$ difference between both chambers was $2.7 \pm 0.3^{\circ} \mathrm{C}$. There were no significant differences between temperatures in situ and those inside the ambient chamber (paired $t$-test, $\mathrm{n}=12, \mathrm{p}>0.1$ ), while there were differences between in situ temperatures and those inside the warmer chamber (paired $t$-test, $\mathrm{n}=12, \mathrm{p}<0.01$ ).

\section{Microorganisms in the Bay of Blanes}

The abundance of heterotrophic bacteria at the start of the incubation varied between $4.8 \times 10^{5}$ cells $\mathrm{ml}^{-1}$ in June and $1.47 \times 10^{6}$ cells $\mathrm{ml}^{-1}$ in December (Fig. 1B, Table 1). The average single-cell biomass of bacteria varied between $10.1 \mathrm{fg} \mathrm{C}^{\mathrm{C}} \mathrm{cll}^{-1}$ in September and $14.3 \mathrm{fg} \mathrm{C}$ cell $^{-1}$ in July; thus, the total bacterial biomass varied between $6.7 \mu \mathrm{g} \mathrm{C} \mathrm{l}^{-1}$ in October and $16.7 \mu \mathrm{C}^{-1}$ in December. The abundance of heterotrophic nanoflagellates oscillated between $1.5 \times 10^{3}$ cells $\mathrm{ml}^{-1}$ in November and $4.4 \times 10^{3}$ cells $\mathrm{ml}^{-1}$ in May (Fig. 1B, Table 1), and the cellular biomass of heterotrophic nanoflagellates varied between $1.4 \times 10^{3} \mathrm{fg} \mathrm{C} \mathrm{cell}^{-1}$ in March and $3.1 \times 10^{3} \mathrm{fg} \mathrm{C}$ cell $^{-1}$ in October; thus, the total biomass of heterotrophic nanoflagellates varied between $2.4 \mu \mathrm{g} \mathrm{C} \mathrm{l^{-1 }}$ in March and $10.7 \mu \mathrm{g} \mathrm{C} \mathrm{l}^{-1}$ in May. The abundance of ciliates varied between $0.2 \times$
$10^{3}$ cells $1^{-1}$ in March and $3.5 \times 10^{3}$ cells $1^{-1}$ in December, and they were especially abundant in winter (Fig. 1B, Table 1). The average cellular biomass of ciliates varied between $23.2 \mathrm{pg} \mathrm{C}^{-1} \mathrm{Cell}^{-1}$ for Balanion sp. and $1.8 \times 10^{3} \mathrm{pg} \mathrm{C}$ cell ${ }^{-1}$ for tintinnids. Thus, the total biomass of ciliates varied between $<0.1 \mu \mathrm{g} \mathrm{C} \mathrm{l}^{-1}$ in April and $1.4 \mu \mathrm{g} \mathrm{C}^{-1}$ in December. The abundance of dinoflagellates varied between $0.2 \times 10^{2}$ cells $1^{-1}$ in April and $15.3 \times 10^{3}$ cells $1^{-1}$ in August, and they were particularly abundant in summer and autumn (Fig. 1B, Table 1). The average cellular biomass of dinoflagellates varied between $128 \mathrm{pg} \mathrm{C}$ cell $^{-1}$ for the smallest dinoflagellates and $6.5 \times 10^{3} \mathrm{pg}$ $\mathrm{C}$ cell $^{-1}$ for Ceratium sp. Thus, the total biomass of

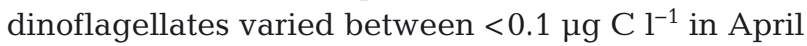
and $3.3 \mu \mathrm{g} \mathrm{C} \mathrm{l}^{-1}$ in August.
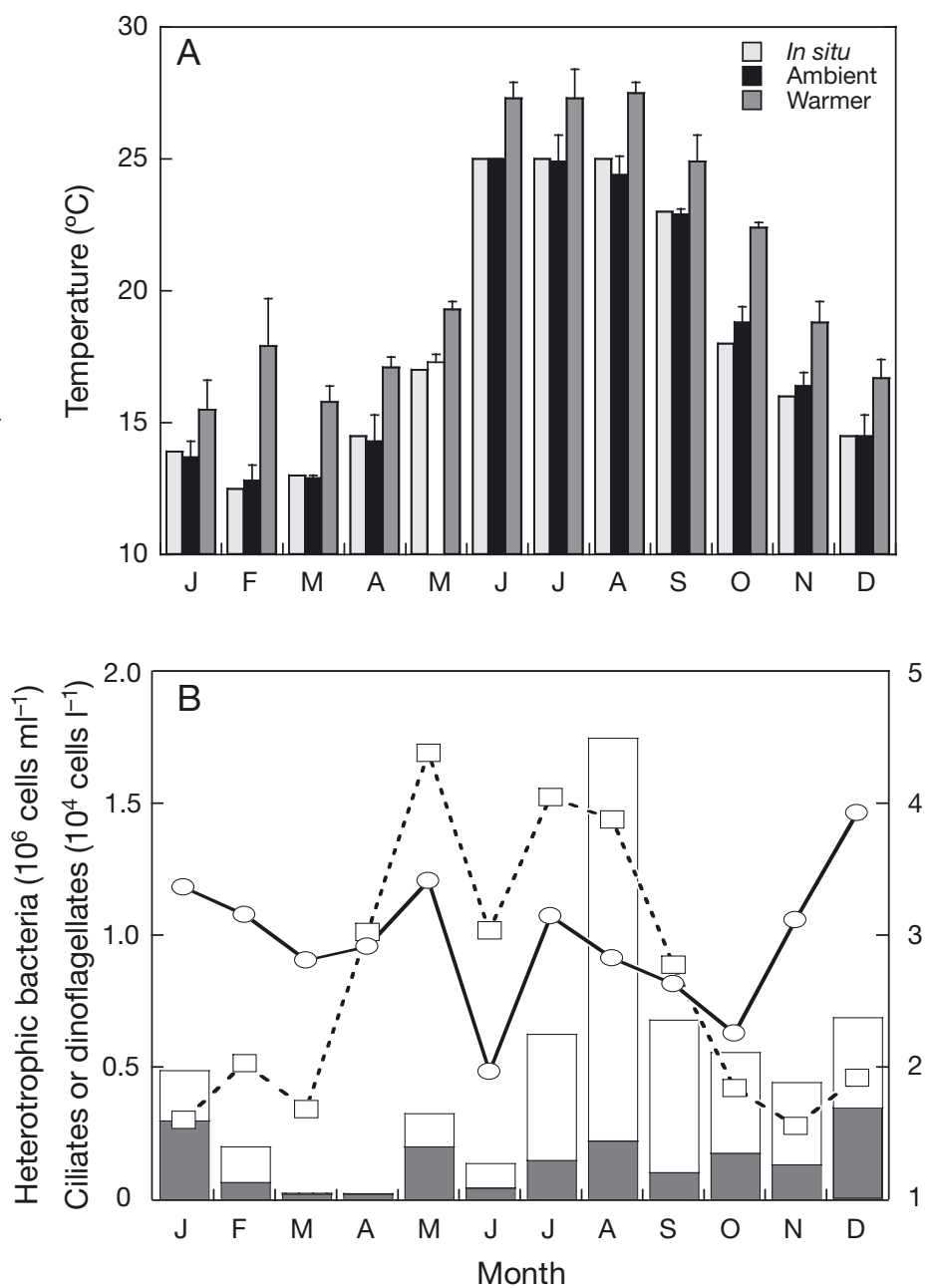

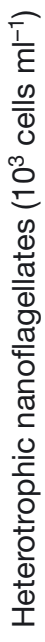

Fig. 1. (A) In situ temperature in the Bay of Blanes and temperatures inside the ambient and warmer chambers. (B) Initial abundance of heterotrophic bacteria $\left(10^{6}\right.$ cells $\left.\mathrm{ml}^{-1} ; \bigcirc\right)$, heterotrophic nanoflagellates $\left(10^{3}\right.$ cells ml $\left.\mathrm{m}^{-1} ; \square\right)$, dinoflagellates $\left(10^{4}\right.$ cells $^{-1}$; white bars $)$, and ciliates $\left(10^{4}\right.$ cells $1^{-1}$; gray bars $)$ 
Table 1. Minimum, maximum and average $( \pm 1 \mathrm{SE})$ abundance and biomass of microorganisms present in the Bay of Blanes, based on measurements at the start of each of the monthly incubations in the $<200 \mu \mathrm{m}$ fraction. ${ }^{*}$ Data only available for May, June, July, and September

\begin{tabular}{|c|c|c|c|}
\hline Microorganisms & Minimum & Maximum & Average \\
\hline \multicolumn{4}{|l|}{$\begin{array}{l}\text { Abundance }\left(10^{5} \text { [bacteria] or }\right. \\
\left.10^{3} \text { [nanoflagellates] cells } \mathrm{ml}^{-1}\right)\end{array}$} \\
\hline Heterotrophic bacteria & 4.8 (Jun) & 14.7 (Dec) & $9.8 \pm 0.8$ \\
\hline Heterotrophic nanoflagellates & 1.5 (Mar) & 4.4 (May) & $2.6 \pm 0.3$ \\
\hline \multicolumn{4}{|l|}{ Abundance $\left(10^{3}\right.$ cells $\left.1^{-1}\right)$} \\
\hline Dinoflagellates & 0.02 (Apr) & 15.34 (Aug) & $3.5 \pm 1.2$ \\
\hline Ciliates & 0.41 (Jun) & 3.48 (Dec) & $1.4 \pm 0.3$ \\
\hline \multicolumn{4}{|l|}{$\begin{array}{l}\text { Single-cell biomass } \\
\left(\mathrm{fg}^{\mathrm{a}}, \mathrm{pg}^{\mathrm{b}}, \text { or } \mathrm{ng}^{\mathrm{c}} \mathrm{C} \text { cell }^{-1}\right)\end{array}$} \\
\hline Heterotrophic bacteria $^{\mathrm{a}}$ & 10.1 (Sep) & 14.3 (Jul) & $11.8 \pm 0.5$ \\
\hline Heterotrophic nanoflagellates ${ }^{b}$ & 1.4 (Mar) & 3.1 (Oct) & $2.5 \pm 0.1$ \\
\hline Dinoflagellates ${ }^{*, c}$ & 0.2 (Sep) & 4.5 (Jun) & $2.0 \pm 0.5$ \\
\hline Ciliates $^{\mathrm{b}}$ & 68.7 (Jun) & 298.6 (Dec) & $170.2 \pm 24$ \\
\hline \multicolumn{4}{|l|}{ Total biomass ( $\mu \mathrm{g} \mathrm{C} \mathrm{1^{-1 } )}$} \\
\hline Heterotrophic bacteria & 6.7 (Oct) & 16.7 (Dec) & $11.5 \pm 0.6$ \\
\hline Heterotrophic nanoflagellates & 2.4 (Mar) & 10.7 (May) & $5.3 \pm 0.7$ \\
\hline Dinoflagellates & 0.01 (Apr) & 3.3 (Aug) & $1.2 \pm 0.3$ \\
\hline Ciliates & 0.02 (Apr) & $1.4(\mathrm{Dec})$ & $0.3 \pm 0.1$ \\
\hline
\end{tabular}

\section{Growth and predation rates}

The bacterial gross growth rates $\left(\mu_{0.8}\right)$ varied between $-0.1 \pm 0.1 \mathrm{~d}^{-1}$ in April and $1.4 \pm 0.2 \mathrm{~d}^{-1}$ in June (Fig. $2 \mathrm{~A})$, with negative values indicating losses of bacteria during the incubations. Similarly, the bacterial net growth rates $\left(\mu_{200}\right)$ varied between $0 \mathrm{~d}^{-1}$ in April and $1.0 \pm 0.2 \mathrm{~d}^{-1}$ in June (Fig. 2B). Thus, the loss rates of heterotrophic bacteria varied between $-0.1 \pm$ $0.2 \mathrm{~d}^{-1}$ in April and $0.6 \pm 0.2 \mathrm{~d}^{-1}$ in July (Fig. 2C), with negative loss rates related to higher bacterial growth rates in the presence of protists (i.e. $\mu_{200}>$ $\left.\mu_{0.8}\right)$. The maximum differences between the gross growth rates in the warmer and ambient temperatures (Fig. 2D) were found in winter, when temperatures in situ were the lowest of the year, and such differences decreased in summer, when temperatures in situ where the highest. How-
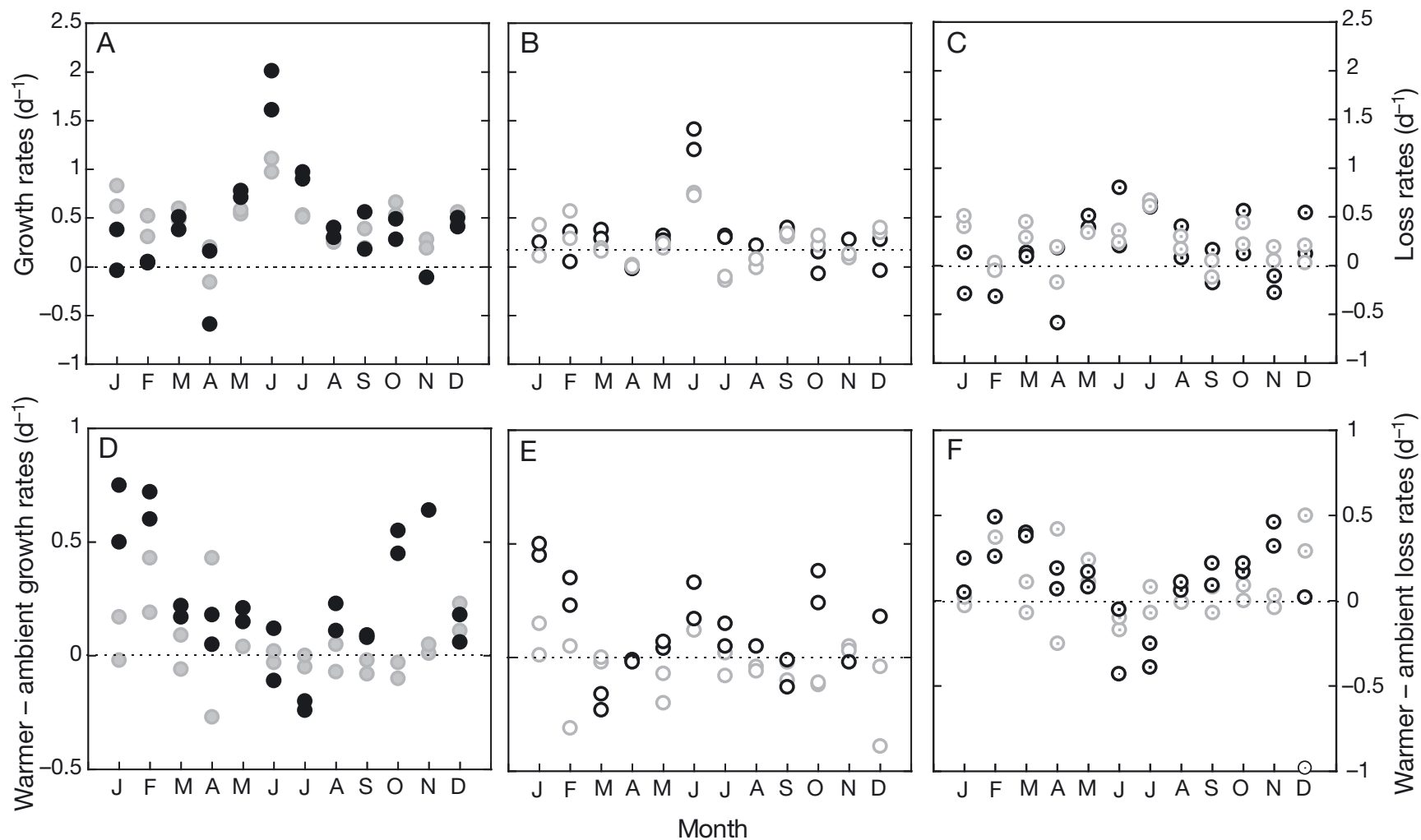

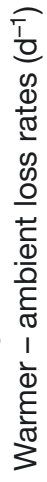

Fig. 2. Rates of (A) bacterial gross growth, (B) net growth, and (C) losses to grazing at the ambient conditions. (D-F) Difference between the same rates measured in the warmer conditions and those measured in the ambient conditions. The different rates were determined between 0 and $24 \mathrm{~h}$ (black symbols) and 0 and $48 \mathrm{~h}$ (gray symbols) 
Table 2. Different variables measured during 12 incubations under ambient and warmer conditions with 2 size fractions $(<0.8$ and $<200 \mu \mathrm{m})$ of seawater from the Bay of Blanes. Average values $( \pm 1 \mathrm{SE})$ in ambient conditions, and average difference ( $\pm 1 \mathrm{SE}$ ) with the same variable under the warmer conditions. Negative values of the difference indicate a lower value under the warmer conditions. The $\mathrm{p}$ corresponds to the significance of the paired $t$-tests between the values at both temperatures, testing for the temperature effect; significant values in bold. ns: not significant; -: not determined

\begin{tabular}{|c|c|c|c|c|}
\hline Treatment and variable & Ambient temperature & Difference & $Q_{10}$ & Paired $t$-test, $\mathrm{p}$ \\
\hline \multicolumn{5}{|l|}{$<0.8 \mu \mathrm{m}$ treatment } \\
\hline Bacterial biomass $\left(\mu \mathrm{g} \mathrm{C} \mathrm{^{-1 } )}\right.$ & $14.6 \pm 1.7$ & $2.9 \pm 0.9$ & $1.9 \pm 0.1$ & $<0.01$ \\
\hline Bacterial gross growth rate $\left(\mathrm{d}^{-1}\right)$ & $0.5 \pm 0.1$ & $0.1 \pm 0.1$ & $2.8 \pm 0.1$ & $<0.01$ \\
\hline 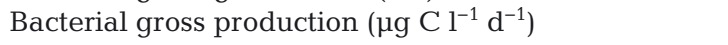 & $2.0 \pm 0.3$ & $0.5 \pm 0.2$ & $2.8 \pm 0.1$ & $<0.01$ \\
\hline \multicolumn{5}{|l|}{$<200 \mu \mathrm{m}$ treatment } \\
\hline Bacterial biomass $\left(\mu \mathrm{g} \mathrm{Cl}^{-1}\right)$ & $18.7 \pm 2.1$ & ns & - & 0.08 \\
\hline Bacterial net growth rate $\left(\mathrm{d}^{-1}\right)$ & $0.3 \pm 0.1$ & ns & - & 0.05 \\
\hline Bacterial net production $\left(\mu \mathrm{g} \mathrm{C} \mathrm{l}^{-1} \mathrm{~d}^{-1}\right)$ & $1.9 \pm 0.4$ & ns & - & 0.07 \\
\hline Loss rates of heterotrophic bacteria $\left(\mathrm{d}^{-1}\right)$ & $0.2 \pm 0.1$ & $0.1 \pm 0.1$ & $3.4 \pm 0.4$ & $<0.05$ \\
\hline Bacterial biomass lost to grazers $\left(\mu \mathrm{g} \mathrm{C} \mathrm{l}^{-1} \mathrm{~d}^{-1}\right)$ & $1.6 \pm 0.6$ & $0.7 \pm 0.5$ & $3.8 \pm 0.4$ & $<0.05$ \\
\hline Heterotrophic nanoflagellate biomass $\left(\mu \mathrm{g} \mathrm{C}^{-1}\right)$ & $10.4 \pm 2.5$ & $-2.5 \pm 0.4$ & - & $<0.01$ \\
\hline Heterotrophic nanoflagellate net growth rate $\left(\mathrm{d}^{-1}\right)$ & $0.2 \pm 0.1$ & ns & - & 0.30 \\
\hline Heterotrophic nanoflagellate net production $\left(\mu \mathrm{g} \mathrm{C} \mathrm{l}^{-1}\right)$ & $4.7 \pm 1.4$ & $-2.5 \pm 0.4$ & - & $<0.01$ \\
\hline Ciliate biomass $\left(\mu \mathrm{C} \mathrm{C}^{-1}\right)$ & $0.3 \pm 0.1$ & ns & - & 0.30 \\
\hline Ciliate net growth rate $\left(\mathrm{d}^{-1}\right)$ & $-0.3 \pm 0.1$ & $-0.2 \pm 0.1$ & - & 0.05 \\
\hline Dinoflagellate biomass $\left(\mu \mathrm{g} \mathrm{C} \mathrm{l}^{-1}\right)$ & $5.1 \pm 2.1$ & ns & - & 0.11 \\
\hline Dinoflagellate net growth rate $\left(\mathrm{d}^{-1}\right)$ & $0.1 \pm 0.1$ & ns & - & 0.50 \\
\hline
\end{tabular}

ever, the seasonality of the gross growth rates was not observed on the bacterial net growth rates and, thus, when predators were present (Fig. 2E). Conversely, the bacterial losses to grazers showed the same seasonality as the bacterial gross growth rates, with maximum values reached in winter and negative values in summer (Fig. 2F).

In the absence of predators $(<0.8 \mu \mathrm{m})$, the warmer conditions produced a significant increase in bacterial biomass $(20 \%)$, gross growth rates $(25 \%)$, and bacterial gross production rates $(25 \%)$, with $Q_{10}$ values between 1.9 and 2.8 (Table 2). When predators were present $(<200 \mu \mathrm{m})$, the warmer conditions did not produce significant changes in the average bacterial biomass, the net growth rates, and the bacterial net production rates (Table 2). However, warming produced an increase of ca. 40 to $50 \%$ in the average loss rate of heterotrophic bacteria and the bacterial biomass lost to grazers, with corresponding $Q_{10}$ values close to 3.5 (Table 2).

\section{Microbial top predators}

During the incubation at ambient temperature, the net growth rates of heterotrophic nanoflagellates varied between $-0.5 \pm 0.2 \mathrm{~d}^{-1}$ in September and $0.7 \pm$ $0.1 \mathrm{~d}^{-1}$ in July. The net growth rates of ciliates varied between a minimum of $-0.8 \pm 0.1 \mathrm{~d}^{-1}$ in June and a maximum of $0.7 \pm 0.3 \mathrm{~d}^{-1}$ in April, and those of dino- flagellates varied between a minimum of $-0.6 \pm 0.1 \mathrm{~d}^{-1}$ in February and a maximum of $0.7 \mathrm{~d}^{-1}$ in December (Fig. 3A-C). Decreases in the growth rates of heterotrophic nanoflagellates in the spring were coincident with sharp increases in the growth rates of ciliates and dinoflagellates, which may be indicative of a tight coupling between the heterotrophic nanoflagellates and their top predators. Warming did not significantly affect the growth rates of heterotrophic nanoflagellates (Fig. 3D, Table 2); it triggered decreases in growth rates of ciliates (Fig. 3E, Table 2), and had a complex effect on the growth rates of dinoflagellates, with an increase in some months and a decrease or a lack of effect in others (Fig. 3F). In the warmer conditions, the total biomass and net production of heterotrophic nanoflagellates decreased by 24 and $55 \%$, respectively (Table 2), a pattern driven by the lower cell volume of heterotrophic nanoflagellates that decreased from 11.5 to $7.6 \mu^{3}$ (paired $t$ test, $\mathrm{p}<0.01$ ).

In a closer inspection of the different groups of microbial top predators, the most abundant groups in situ were the small dinoflagellates and Strombidium sp. (Fig. 4A). After incubation in the ambient conditions, there was a decrease in Strombidium sp., Mesodinium sp., Strombidium conicum, and Halteria sp., while in the warmer conditions, there was a decrease in Strombidium sp., Mesodinium sp., Strombidium conicum, Strombidium acutum, Laboea sp., Balanion sp., Halteria sp., and unknown ciliates 

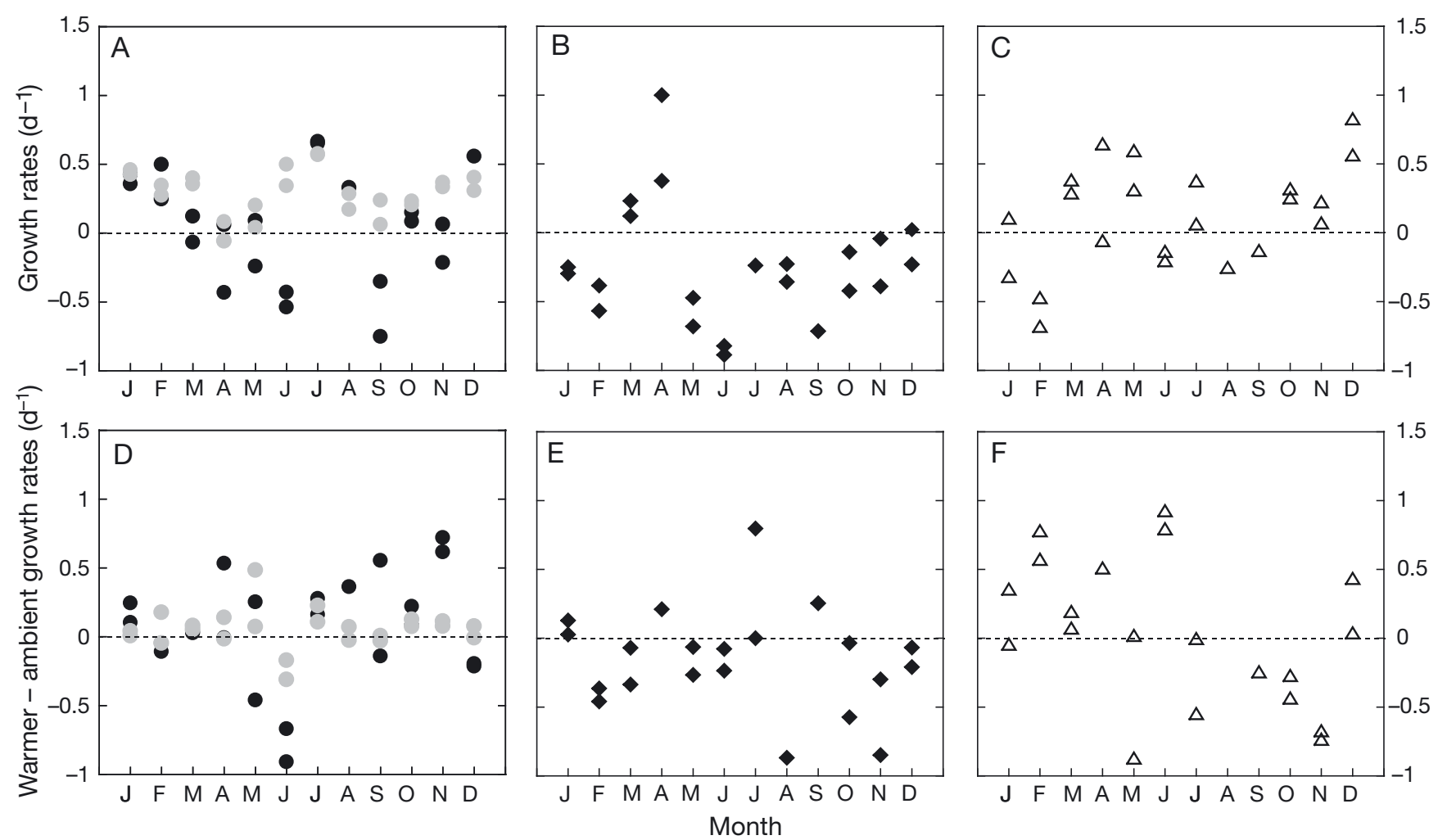

Fig. 3. Rates of gross growth of (A) heterotrophic nanoflagellates, (B) ciliates and (C) dinoflagellates at ambient temperature. $(\mathrm{D}, \mathrm{E}, \mathrm{F})$ Difference between the same rates measured in the warmer conditions and those measured in the ambient conditions.

The different rates were determined between 0 and $24 \mathrm{~h}$ (black symbols) and 0 and $48 \mathrm{~h}$ (gray symbols)

(Fig. 4A). Small dinoflagellates and Ceratium sp. increased in abundance in the ambient and warmer conditions, Prorocentrum sp. decreased in abundance in the ambient and warmer conditions, and Gymnodinium sp. decreased in abundance in the warmer conditions (Fig. 4A). Differences between protist abundances in the ambient and warmer conditions indicate that warming produced a general decrease in the abundance of ciliates and dinoflagellates (Fig. 4B). Overall, ciliates decreased more in the warmer conditions, and dinoflagellates tended to increase less in the warmer conditions (Fig. 4C).

\section{Diversity of the microbial top predators}

The taxonomic richness of the Bay of Blanes microplankton top predators ranged between 10 taxa in summer (e.g. July) and 17 taxa in winter (e.g. December and January), with ciliate richness varying between 6 taxa in summer and 13 taxa in winter. The Margalef index of diversity varied between 2.4 in July and 6.0 in March (Fig. 5A), the Shannon index of diversity of microplankton top predators varied in situ between 1.0 in September and 2.0 in May (Fig. 5B), and the evenness of the samples (measured by the modified Hill's number) varied between 0.4 in August and 0.8 in March (Fig. 5C). The average Margalef index of diversity in situ, $4 \pm 0.3$, decreased significantly (ANOVA, $F=19.4, \mathrm{n}=36, \mathrm{p}<0.001$ ) during the incubations to similar values at ambient, $2.3 \pm 0.2$, and warmer conditions, $2.3 \pm 0.1$, and there were no significant differences between Margalef indexes at the ambient and warmer conditions (Fig. 5D; paired $t$-test, $\mathrm{p}>0.1, \mathrm{n}=12$ ). This decrease was not observed in the Shannon index of diversity nor in the evenness measured by the modified Hill's number related to the incubation of the samples. In addition, the average Shannon index of diversity of the microplankton top predators was $1.4 \pm 0.1$ at ambient temperature and $1.3 \pm 0.2$ in the warmer conditions, and there were no significant differences between temperatures (Fig. 5D; paired $t$-test, $\mathrm{p}>0.1, \mathrm{n}=12$ ). Finally, the same happened with the evenness of the samples, and the average value at ambient temperature, $0.5 \pm 0.1$, was not significantly different from that observed in the warmer conditions, $0.5 \pm 0.2$ (Fig. 5D, paired $t$-test, $\mathrm{p}>0.1, \mathrm{n}=12$ ). 


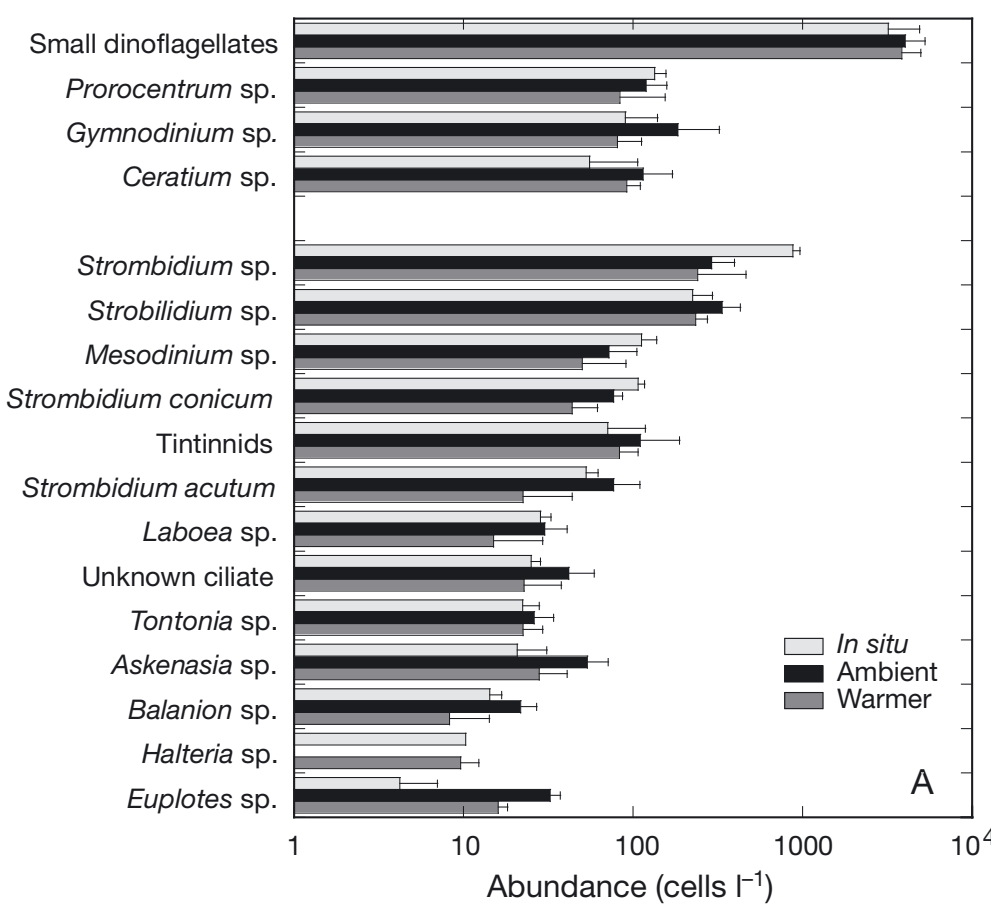

Fig. 4. (A) Abundance of the top microbial predators in situ and after $48 \mathrm{~h}$ of incubation in the ambient and warmer conditions. (B) Differences in the abundances of the same top microbial predators in the ambient and warmer conditions ( ${ }^{*}$ negative value). (C) Relationships between the in situ abundance and the abundance in the warmer (gray symbols) and ambient (black symbols) conditions of ciliates (filled symbols, continuous lines) and dinoflagellates (open symbols, dashed lines). Regression lines: Ciliates ambient $\left(\right.$ cells $\left.l^{-1}\right)=(7.78 \pm 1.5) \times$ Ciliates in situ $\left(\text { cells } 1^{-1}\right)^{0.55}$ $\pm 0.1, \mathrm{r}^{2}=0.69, \mathrm{p}<0.01$. Ciliates warmer $\left(\right.$ cells $\left.\mathrm{l}^{-1}\right)=(2.64 \pm 1.6) \times$ Ciliates in situ (cells $\left.1^{-1}\right)^{0.67 \pm 0.1}, \mathrm{r}^{2}=0.75, \mathrm{p}<0.01$. Dinoflagellates ambient $\left(\right.$ cells $\left.1^{-1}\right)=(2.44 \pm 2.2) \times$ Dinoflagellates in situ (cells $\left.\mathrm{l}^{-1}\right)^{0.906 \pm 0.1}, \mathrm{r}^{2}=0.99, \mathrm{p}<0.01$. Dinoflagellates warmer $\left(\right.$ cells $\left.\mathrm{l}^{-1}\right)=$ $(0.97 \pm 2.5) \times$ Dinoflagellates in situ $\left(\text { cells } l^{-1}\right)^{1.01} \pm 0.1, r^{2}=0.99$,

$$
\mathrm{p}<0.01
$$

\section{DISCUSSION}

\section{Methodological considerations}

The initial concentration and metabolic rates of microorganisms were within the usual range found in the Bay of Blanes (cf. Alonso-Sáez et al. 2008, Vaqué et al. 1997). In this ecosystem, the heterotrophic bacteria are mainly removed by heterotrophic and mixotrophic nanoflagellates (Unrein et al. 2007) and by viruses (Boras et al. 2009). However, as the bacterial mortality rates were estimated by the difference between the bacterial growth rates measured in the 0.8 and $200 \mu \mathrm{m}$ fractions, the bacterial losses related to viruses were considered in both fractions. In addition, plastidic nanoflagellates (including the mixotrophic ones) decreased exponentially under dark conditions

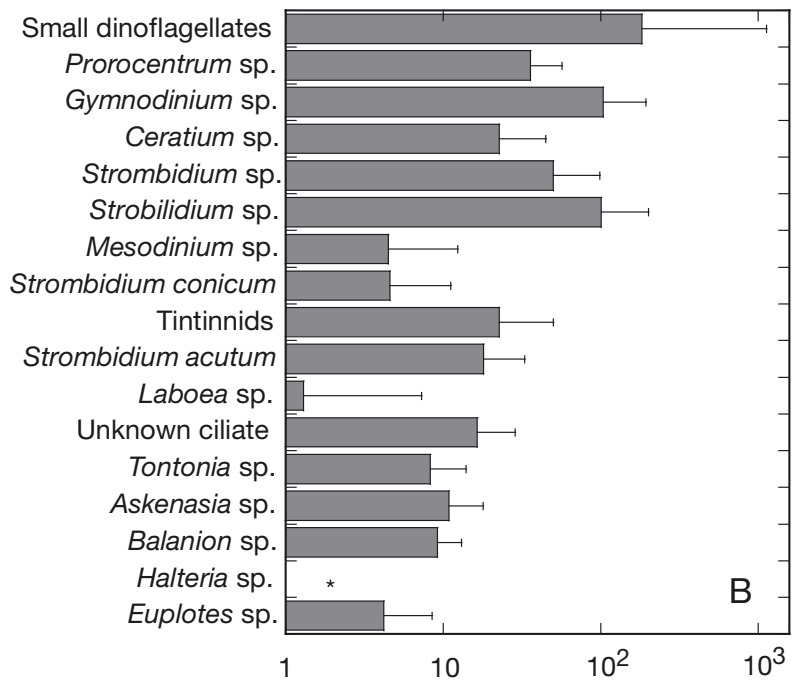

Abundance: ambient - warmer conditions (cells I $^{-1}$ )

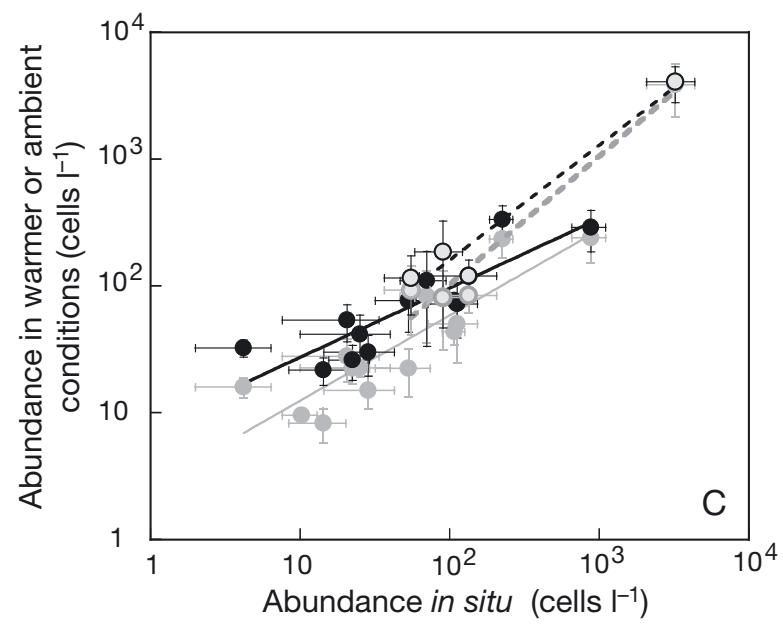

(details not shown), and thus most bacterial losses were caused by heterotrophic protists. In this sense, differential filtration is one of the methods used to estimate bacterial losses to predation, and there are alternative methods, such as the dilution technique (Landry \& Hassett 1982) or the fluorescent tracer method (Sherr et al. 1987, Vázquez-Domínguez et al. 1999). However, even if the method can influence the absolute bacterial losses to grazing (Vaqué et al. 1994), the use of one particular method does not influence the comparison between treatments. Something similar happens with the bacteria lost at the start of the incubation during filtration through $0.8 \mu \mathrm{m}$ filters, which (1) may produce an underestimation of the losses to grazing if the growth rates were influenced by the initial concentration of bacteria, but (2) does not influence the differences between treatments. 

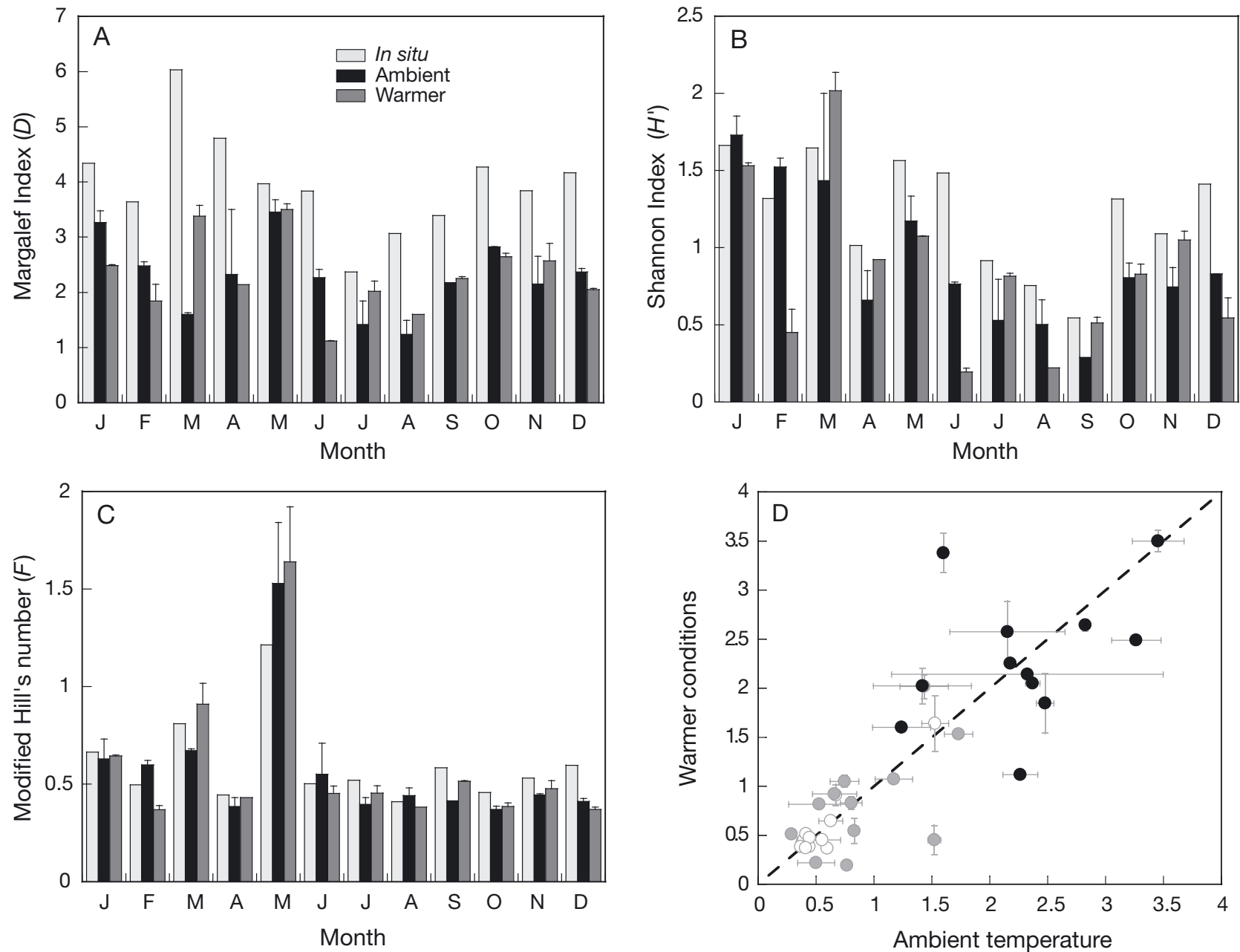

Fig. 5. Diversity of microbial top predators. (A) Margalef index of diversity, (B) Shannon index of diversity, and (C) evenness (modified Hill's numbers) in situ and after incubation in the ambient and warmer conditions. (D) Estimates of microplankton top predator diversity (Shannon [O] or Margalef [○] indices) and evenness (modified Hill's numbers [๑]) measured at the ambient temperature and under the warmer conditions. The dashed line is the 1:1 relationship. Error bars in all panels correspond to $1 \mathrm{SE}$

In the present study, the increment of temperature (near $2.7^{\circ} \mathrm{C}$ ) was accomplished after few hours of incubation $(<12 \mathrm{~h})$, and such a large change is not usual under natural conditions. However, in the Bay of Blanes, differences $>1{ }^{\circ} \mathrm{C}$ within day-night periods are common (Ruíz-González et al. 2012), and a warming of $4^{\circ} \mathrm{C}$ has been observed during short periods of time in the vicinity of the thermal effluents of power stations in coastal ecosystems (Choi et al. 2002). Thus, the warming produced in our incubations could be found under certain natural conditions.

Richness, diversity, and evenness of the microbial top predators are underestimated compared to the values measurable with molecular tools (Caron et al. 2012), but the combination of the acidic Lugol fixation and the Utermöhl technique is an accepted protocol to study changes in morphospecies within microplankton assemblages (i.e. Aberle et al. 2007). Thus, rather than the absolute magnitude of change, the present study is focused on the influence of the warming conditions on the relative changes of the growth and consumption rates of microorganisms and on the community composition of microbial top predators.

\section{Function and seasonality of heterotrophic microplankton}

In the Bay of Blanes, experimental warming produced an increase in biomass and gross production rates of heterotrophic bacteria. The increases in gross production rates $(\sim 25 \%)$ were close to those measured in the same samples through ${ }^{3} \mathrm{H}$-leucine 
incorporation (Vázquez-Domínguez et al. 2007) and are similar to what has been observed in other regions, e.g. the Kiel Bight (Wohlers et al. 2009). The loss rates of heterotrophic bacteria to grazing increased with warming by nearly $50 \%$, results that agree with the increase in bacterial production and grazing rates with warming in Antarctic waters (Vaqué et al. 2009). However, in the latter study, warming produced larger responses in the bacterial production rates compared to the bacterial losses to grazing, which could be related to the fact that the growth rates of bacterivorous protists were likely to be constrained at very low temperatures (Rose \& Caron 2007). Recently, a metadata analysis of several aquatic ecosystems has also shown that warmer conditions lead to smaller increases in bacterial growth rates compared to the bacterial losses to grazing (Sarmento et al. 2010). Thus, we should expect that a small increase in temperature would lead to an increment in the top-down control of bacterial abundance. Conversely, if the $Q_{10}$ for the bacterial growth rates is higher than for the loss rates, bacteria would outcompete their predators and would not be controlled by grazing. If warming increases either the bacterial production rates or the bacterial losses to grazing, there would be an increase in the return of $\mathrm{CO}_{2}$ to the ecosystem through respiration processes.

Warming produced an effect on bacterial gross growth rates, with a clear seasonality. In winter, when the experimentally increased temperature in the warmer conditions was $>15 \%$ over the in situ values, the increases in bacterial gross growth rates were more relevant than in summer, when the experimentally increased temperature rises were $<10 \%$ above the in situ values. One of the factors that can modulate the response of bacterial production to warming is the availability of resources (Shiah \& Ducklow 1994). In the Bay of Blanes, bacterial carbon demand (bacterial production and bacterial respiration) during winter is lower than total primary production (Alonso-Sáez et al. 2008), and thus an increase in temperature may lead to an increase in bacterial production that can be fueled by primary producers. This would not happen in summer, when bacterial carbon demand is much higher than primary production (Alonso-Sáez et al. 2008). Something similar has been observed in Chesapeake Bay, where temperature regulates bacterial production rates below $20^{\circ} \mathrm{C}$, and nutrients are more important when in situ temperatures are above this threshold (Shiah \& Ducklow 1994).

Bacterial losses to grazing also presented a clear seasonality, with higher increases in winter and lower in summer. This seasonality could be related to both a higher influence of temperature on the grazing rates of protists when temperatures are below $18^{\circ} \mathrm{C}$ (Vaqué et al. 1994) or an enhancement of bacterivorous protists growth rates with temperature (Rose \& Caron 2007). Conversely, heterotrophic protists would not be able to increase their grazing rates to the point that temperature alone would allow during summer, as their growth rates would be limited by prey growth.

The increases in the losses to grazing with warming were not transformed into an increase in the abundance, biomass, or net production of heterotrophic nanoflagellates. Thus, heterotrophic nanoflagellates were probably ingesting a larger amount of bacteria under warmer conditions, but they reached a smaller biomass toward the end of the incubations. This could be related to (1) higher protist respiration (e.g. Rivkin \& Legendre 2001), (2) a negative effect of temperature on protist cell size (Atkinson et al. 2003, Montagnes et al. 2008), and/or (3) a higher predation rate by ciliates and dinoflagellates on the larger heterotrophic nanoflagellates. The warmer conditions had a significant negative effect on the size of heterotrophic nanoflagellates, and the same happened with the growth rates of ciliates. If warming increased the grazing rates on heterotrophic nanoflagellates by ciliates or dinoflagellates, this could quickly be translated into copepod nauplii by an efficient trophic cascade. This finding is in contrast to that observed in the Thau Lagoon (Vidussi et al. 2011), where ciliates showed a rapid response to warming related to both a greater abundance of their potential prey (i.e. heterotrophic nanoflagellates) and scarcity of their potential predators (i.e. copepods).

There are inherent difficulties in modeling the flow of carbon among different components of the microbial food web by $Q_{10}$ functions. Warming produced different effects on different groups of microbial top predators: the small dinoflagellates and Ceratium sp. developed slightly better under warmer conditions than those in situ, while there was a negative effect of warming on ciliates. Such results could be related to both the positive effect of temperature on the growth rates and the nonlinear interactions between temperature and food concentration. When food is in excess, the production rates of ciliates can increase linearly with temperature (Weisse et al. 2002). However, the maximum growth rates of Urotricha fracta may increase with warming, while their cellular volume may decrease, thus leading to maximum biomasses at intermediate temperatures (Montagnes et al. 2008). Then, the negative effect of temperature on 
ciliate net growth rates could be related to different factors: a lower biomass of their prey (Montagnes et al. 2008), a higher predation by the copepod nauplii present in the samples (Huntley \& Lopez 1992), or lower protist growth efficiency with warming (Rivkin \& Legendre 2001). Similarly, temperature has a positive effect on the net growth rate of dinoflagellates (Baek et al. 2008; Nagasoe et al. 2006), which may explain the positive effect of warming on the abundance of small dinoflagellates and Ceratium sp.

\section{Changes in the community composition of the microplankton top predators}

Our experiment was perhaps too short to detect changes in microbial community structure, but the bacterial community structure of a lake was seen to change in $24 \mathrm{~h}$ incubations (Gattuso et al. 2002), and the diversity of tintinnids in the Chesapeake Bay changed significantly during the same period of time (Dolan \& Gallegos 2001). Dinoflagellate and ciliate growth rates are on the order of 1 or 2 duplications per day (Hansen et al. 1997), and microplankton could have had $\sim 4$ duplications within the time frame of our experiments. Thus, unless equal for all species, the functional changes induced by warming should be detectable and assigned to a change in the diversity of the microplankton top predators.

After $48 \mathrm{~h}$ incubation, the abundance of dinoflagellates increased and that of ciliates decreased independently of the incubation temperature. However, the increase in dinoflagellates was smaller and the decrease in ciliates was larger in the warmer conditions. Such findings are in accordance with those found in the Ligurian Sea (NW Mediterranean), where dinoflagellates increased their abundance over other groups of protists when variations in the North Atlantic oscillation increased the temperature and decreased the inorganic nutrient concentrations of surface waters (Gómez \& Gorsky 2003). In addition, the change in the abundance of ciliates and dinoflagellates did not drive any significant change in the diversity or the evenness of the microplankton top predators. This is similar to what was observed recently in Kiel Bight, where warming changed the succession of different ciliate taxa without significant changes in diversity (Aberle et al. 2007). However, it is in contrast with the extinction of microplanktonic herbivores under warmer conditions reported from laboratory experiments (Petchey et al. 1999). In the Bay of Blanes, warming had a more pronounced negative effect on the bacterivorous Strobilidium sp. than on larger herbivorous ciliates, such as Strombidium sp., tintinnids or Tontonia sp. The difference between the present study and that of Petchey et al. (1999) could be related to the different approaches used. In the laboratory-based approach, the intention was to study the evolution of the same community of microorganisms subjected to a gradual and constant change in temperature. Thus, the total increase in temperature $\left(+14^{\circ} \mathrm{C}\right)$ was produced by small weekly increments $\left(+2^{\circ} \mathrm{C}\right)$, corresponding to 50 to 100 protist generations. However, the approach of the present study is to focus upon the increments of temperature that microplankton communities could experience in the field within short periods of high warming and the immediate changes of metabolism that the same microbial communities subjected to different environmental conditions can present.

Temperature affected the transfer of carbon in the analyzed ecosystem without large changes in the diversity of the microbial top predators, which suggests a certain degree of diversity resilience to warming, as has been observed for phytoplankton species in the North Sea (Wiltshire et al. 2008). In this sense, depending on the timescale of interest, there could be different responses of the microplankton to the temperature stresses to which they are exposed. Over short periods of high warming, the same community could function differently depending on the temperature of the ecosystem. However, if the change is gradual and over long periods of time (i.e. decades or centuries), there could be changes in the species composition of the microplankton through species evolutionary adaptation and/or by substitution with non-indigenous species.

\section{Variations in the microbial food web related to warming}

An experimental warming of $6^{\circ} \mathrm{C}$ in mesocosms deployed in the Baltic Sea produced a 3-fold increase in bacterial production and respiration rates while inducing a negative effect on primary production (Hoppe et al. 2008). Thus, warming reduced the total amount of inorganic carbon fixed by the primary producers and increased the amount of $\mathrm{CO}_{2}$ returned to the system (Wohlers et al. 2009). In contrast, warmer conditions in mesotrophic NW Mediterranean waters led to an increase in the abundance of protozooplankton and a decrease in the development time of copepods, but most of the $\mathrm{CO}_{2}$ produced was consumed by phytoplankton primary production (Vidussi et al. 2011). In the Bay of Blanes, in the absence of light, 
there was a positive effect of temperature on bacterial production and losses to predation. Since bacterial growth efficiencies measured in the same samples were not significantly different between the ambient and warmer conditions (Vázquez-Domínguez et al. 2007), the amount of initial dissolved organic carbon consumed by heterotrophic bacteria that could end up as heterotrophic nanoflagellate biomass was higher. However, warming produced a mismatch between successive trophic levels (e.g. Edwards \& Richardson 2004), as temperature led to positive effects on bacterial secondary production and bacterial losses to grazing, while heterotrophic nanoflagellates and ciliates reduced their production. This finding is counter-intuitive because of the known general positive effect of temperature on the growth rates of protists (Rose \& Caron 2007, Rose et al. 2009). However, it is plausible if the growth efficiencies of protists decrease with temperature (Rivkin \& Legendre 2001) and/or if the increases in protist growth rates related to warming are tightly top-down controlled by the copepod nauplii present in the samples (Vidussi et al. 2011), which, furthermore, could have enhanced their metabolic rates by the positive effect of temperature on their metabolism (Huntley \& Lopez 1992, Weisse et al. 2002, Montagnes et al. 2008). Thus, warmer conditions led to higher production rates in the lower trophic levels that were not transformed into enhanced biomass of the higher predators, a pattern that agrees with an increase in the amount of $\mathrm{CO}_{2}$ returned to the system through the microbial food web (Wohlers et al. 2009) and with an increase in the top-down control of protists by copepods (Vidussi et al. 2011).

In the warmer conditions, ciliate growth rates and biomass decreased, and dinoflagellate growth rates did not change. Thus, given this scenario, the biomass of the microplankton community in the Bay of Blanes would decrease, but the differential effect of temperature on dinoflagellates and ciliates would select for the former. Other studies in the North Sea (Edwards \& Richardson 2004) and the Mediterranean Sea (Gómez \& Gorsky 2003) have also shown that dinoflagellates may be positively influenced by warmer conditions.

\section{CONCLUSION}

Warming changed the function of the microbial food web in the Bay of Blanes by increasing the rates of bacterial secondary production and the bacterial carbon flux to predators. However, warming produced small variations in the community composition and in the microbial top predators.
Acknowledgements. This research is a contribution to the IMBER and SOLAS and was supported by projects MALASPINA (Consolider), MOC2, FISOCEAN, FLAME, and MODIVUS (MICIIN, Spain); and BASICS, MEECE and ATP (UE). Thanks are due to V. Balagué and C. Cardelús for organizing sampling at the Blanes Bay Microbial Observatory. Writing of the manuscript was supported by grants SUMMER and STORM (MICIIN, Spain). We acknowledge the help of B. Martinez and several anonymous reviewers.

\section{LITERATURE CITED}

Aberle N, Lengfellner K, Sommer U (2007) Spring bloom succession, grazing impact and herbivore selectivity of ciliate communities in response to winter warming. Oecologia 150:668-681

Alatalo RV (1981) Problems in the measurement of evenness in ecology. Oikos 37:199-204

> Alonso-Sáez L, Vázquez-Domínguez E, Cardelús C, Pinhassi J and others (2008) Factors controlling the seasonality of bacterial carbon flux in a coastal marine system. Ecosystems 11:397-409

Atkinson D, Ciotti BJ, Montagnes DJS (2003) Protists decease in size linearly with temperature: ca. $2.5 \%{ }^{\circ} \mathrm{C}^{-1}$. Proc Biol Sci 270:2605-2611

Azam F, Fenchel T, Field JG, Gray JS, Meyer-Reil LA, Thingstad F (1983) The ecological role of water-column microbes in the sea. Mar Ecol Prog Ser 10:257-263

Baek SH, Shimode S, Kikuchi T (2008) Growth of dinoflagellates, Ceratium furca and Ceratium fusus in Sagami Bay, Japan: the role of temperature, light intensity and photoperiod. Harmful Algae 7:163-173

Boras JA, Montserrat Sala M, Vázquez-Domínguez E, Weinbauer MG, Vaqué D (2009) Annual changes of bacterial mortality due to viruses and protists in an oligotrophic coastal environment (NW Mediterranean). Environ Microbiol 11:1181-1193

Børsheim KY, Bratbak G (1987) Cell volume to cell carbon conversion factors for a bacterivorous Monas sp. enriched from seawater. Mar Ecol Prog Ser 36:171-175

Boyd PW, Strzepek R, Fu F, Hutchins DA (2010) Environmental control of open-ocean phytoplankton groups: now and in the future. Limnol Oceanogr 55:1353-1376

> Brown JH (2004) Toward a metabolic theory of ecology. Ecology 85:1771-1789

> Calbet A, Landry M (2004) Phytoplankton growth, microzooplankton grazing, and carbon cycling in marine systems. Limnol Oceanogr 49:51-57

> Caron DA, Countway PD, Jones AC, Kim DY, Schnetzer A (2012) Marine protistan diversity. Ann Rev Mar Sci 4: 467-493

> Choi DH, Park JS, Hwang CY, Huh SH, Cho BC (2002) Effects of thermal effluents from a power station on bacteria and heterotrophic nanoflagellates in coastal waters. Mar Ecol Prog Ser 229:1-10

Christensen JH, Hewitson B, Busuioc A, Chen A and others (2007) Regional climate projections. In: Solomon S, Qin D, Manning M, Chen Z and others (eds) Climate change 2007: the physical science basis. Contribution of Working Group 1 to the Fourth Assessment Report of the Intergovernmental Panel on Climate Change. Cambridge University Press, Cambridge, p 847-940

Danovaro R, Dell'anno A, Pusceddu A (2004) Biodiversity response to climate change in a warm deep sea. Ecol Lett 


\section{$7: 821-828$}

del Giorgio PA, Cole JJ (1998) Bacterial growth efficiency in natural aquatic systems. Annu Rev Ecol Syst 29:503-541

del Giorgio PA, Bird DF, Prairie YT, Planas D (1996) Flow cytometric determination of bacterial abundance in lake plankton with the green nucleic acid Syto 13. Limnol Oceanogr 41:783-789

$>$ Dolan J, Gallegos CL (2001) Estuarine diversity of tintinnids (planktonic ciliates). J Plankton Res 23:1009-1027

$>$ Ducklow HW, Purdie DA, Williams PJ LeB, Davies JM (1986) Bacterioplankton: a sink for carbon in a coastal marine plankton community. Science 232:865-867

> Edwards M, Richardson AJ (2004) Impact of climate change on marine pelagic phenology and trophic mismatch. Nature 430:881-884

Field CB, Behrenfeld MJ, Randerson JT, Falkowski P (1998) Primary production of the biosphere: integrating terrestrial and oceanic components. Science 281:237-240

Fuhrman JA (1999) Marine viruses and their biogeochemical and ecological effects. Nature 399:541-548

Gasol JM, del Giorgio PA (2000) Using flow cytometry for counting natural planktonic bacteria and understanding the structure of planktonic bacterial communities. Sci Mar 64:197-224

Gasol JM, del Giorgio PA, Duarte CM (1997) Biomass distribution in marine planktonic communities. Limnol Oceanogr 42:1353-1363

- Gattuso JP, Peduzzi S, Pizay MD, Tonolla M (2002) Changes in freshwater bacterial community composition during measurements of microbial and community respiration. J Plankton Res 24:1197-1206

> Gómez F (2003) Checklist of Mediterranean free-living dinoflagellates. Bot Mar 46:215-242

- Gómez F, Gorsky G (2003) Microplankton annual cycles in the Bay of Villefranche, Ligurian Sea, NW Mediterranean Sea. J Plankton Res 25:323-339

Hansen PJ (1991) Quantitative importance and trophic role of heterotrophic dinoflagellates in a coastal pelagial food web. Mar Ecol Prog Ser 73:253-261

> Hansen PJ, Bjørnsen PK, Hansen BW (1997) Zooplankton grazing and growth: scaling within the $2-2,000-\mu \mathrm{m}$ body size range. Limnol Oceanogr 42:687-704

> Hoppe HG, Breithaupt P, Walther K, Koppe R, Bleck S, Sommer U, Jürgens K (2008) Climate warming in winter affects the coupling between phytoplankton and bacteria during the spring bloom: a mesocosm study. Aquat Microb Ecol 51:105-115

> Huntley ME, Lopez MDG (1992) Temperature-dependent production of marine copepods: a global synthesis. Am Nat 140:201-242

> Landry MR, Hassett RP (1982) Estimating the grazing impact of marine micro-zooplankton. Mar Biol 67: 283-288

Levitus S, Antonov JI, Boyer TP, Stephens C (2000) Warming of the world ocean. Science 287:2225-2229

- Li WKW, McLaughlin FA, Lovejoy C, Carmack EC (2009) Smallest algae thrive as the Arctic Ocean freshens. Science 326:539

Lynn DH, Small EB (2002). Phylum Ciliophora Doflein, 1901. In: Lee JJ, Leedale GF, Bradbury P (eds) An illustrated guide to the protozoa, 2nd edn. Society of Protozoologists, Lawrence, KS

> Mackenzie BR, Schiedek D (2007) Daily ocean monitoring since the 1860s shows record warming of northern European seas. Glob Change Biol 13:1335-1347
Marrasé C, Lim EL, Caron DA (1992) Seasonal and daily changes in bacterivory in a coastal plankton community. Mar Ecol Prog Ser 82:281-289

Marrugan AE (2004) Measuring biological diversity. Blackwell Science, Carlton, Victoria

Menden-Deuer S, Lessard EJ (2000) Carbon to volume relationships for dinoflagellates, diatoms and other protist plankton. Limnol Oceanogr 45:569-579

> Montagnes DJS, Morgan G, Bissinger JE, Atkinson D, Weisse $T$ (2008) Short-term temperature change may impact freshwater carbon flux: a microbial perspective. Glob Change Biol 14:2823-2838

> Morán XAG, Sebastián M, Pedrós-Alió C, Estrada M (2006) Response of Southern Ocean phytoplankton and bacterioplankton production to short-term experimental warming. Limnol Oceanogr 51:1791-1800

> Nagasoe S, Kim DI, Shimasaki Y, Oshima Y, Yamaguchi M, Honjo T (2006) Effects of temperature, salinity and irradiance on the growth of the red tide dinoflagellate Gyrodinium instriatum Freudenthal et Lee. Harmful Algae 5: $20-25$

Norland S (1993) The relationship between biomass and volume of bacteria. In: Kemp PF, Sherr BF, Sherr EB, Cole JJ (eds) Handbook of methods in aquatic microbial ecology. Lewis Publishers, Boca Raton, FL

Petchey OL, Mcphearson PT, Casey TM, Morin PJ (1999) Environmental warming alters food-web structure and ecosystem function. Nature 402:69-72

Porter KG, Feig YS (1980) The use of DAPI for identifying and counting aquatic microflora. Limnol Oceanogr 25: 943-948

Rivkin RB, Legendre L (2001) Biogenic carbon cycling in the upper ocean: effects of microbial respiration. Science 291:2398-2400

> Rose JM, Caron DA (2007) Does low temperature constrain the growth rates of heterotrophic protists? Evidence and implications for algal blooms in cold waters. Limnol Oceanogr 52:886-895

Rose JM, Vora NM, Caron DA (2008) Effect of temperature and prey type on nutrient regeneration by an Antarctic bacterivorous protist. Microb Ecol 56:101-111

- Rose JM, Vora NM, Countway PD, Gast RJ, Caron DA (2009) Effects of temperature on growth rate and gross growth efficiency of an Antarctic bacterivorous protist. ISME J 3:252-260

- Ruiz-González C, Lefort T, Massana R, Simó R, Gasol JM (2012) Diel changes in bulk and single-cell bacterial heterotrophic activity in winter surface waters of the northwestern Mediterranean Sea. Limnol Oceanogr 57: $29-42$

Sarmento H, Montoya JM, Vázquez-Domínguez E, Vaqué D, Gasol JM (2010) Warming effects on marine microbial food webs: How far can we go when it comes to predictions? Philos Trans R Soc Lond B 365:2137-2149

- Sherr BF, Sherr EB, Fallon RD (1987) Use of monodispersed, fluorescently labeled bacteria to estimate in situ protozoan bacterivory. Appl Environ Microbiol 53:958-965

> Sherr EB, Sherr BF (1988) Role of microbes in pelagic food webs: a revised concept. Limnol Oceanogr 33:1225-1227

Sherr EB, Sherr BF (1996) Temporal offset in oceanic production and respiration processes implied by seasonal changes in atmospheric oxygen: the role of heterotrophic microbes. Aquat Microb Ecol 11:91-100

Shiah FK, Ducklow HW (1994) Temperature and substrate regulation of bacterial abundance, production and spe- 
cific growth rate in Chesapeake Bay, USA. Mar Ecol Prog Ser 103:297-308

Siegenthaler U, Sarmiento JL (1993) Atmospheric carbon dioxide and the ocean. Nature 365:119-125

Sieracki ME, Johnson PW, Sieburth JM (1985) Detection, enumeration, and sizing of planktonic bacteria by imageanalyzed epifluorescence microscopy. Appl Environ Microbiol 49:799-810

Stoecker DK, Gifford DJ, Putt M (1994) Preservation of marine planktonic cilliates: losses and cell shrinkage during fixation. Mar Ecol Prog Ser 110:293-299

Straile D (1997) Gross growth efficiencies of protozoan and metazoan zooplankton and their dependence on food concentration, predator-prey weight ratio, and taxonomic group. Limnol Oceanogr 42:1375-1385

Tunin-Ley A, Ibañez F, Labat JP, Zingone A, Lemée R (2009) Phytoplankton biodiversity and NW Mediterranean Sea warming: changes in the dinoflagellate genus Ceratium in the 20th century. Mar Ecol Prog Ser 375:85-99

> Unrein F, Massana R, Alonso-Sáez L, Gasol JM (2007) Significant year-round effect of small mixotrophic flagellates on bacterioplankton in an oligotrophic coastal system. Limnol Oceanogr 52:456-469

Vaqué D, Gasol JM, Marrasé C (1994) Grazing rates on bacteria: the significance of methodology and ecological factors. Mar Ecol Prog Ser 109:263-274

- Vaqué D, Blough HA, Duarte CM (1997) Dynamics of ciliate abundance, biomass and community composition in an oligotrophic coastal environment (NW Mediterranean). Aquat Microb Ecol 12:71-83

Vaqué D, Guadayol O, Peters F, Felipe J, Malits A, PédrosAlió C (2009) Differential response of grazing and bacterial heterotrophic production to experimental warming in Antarctic waters. Aquat Microb Ecol 54:101-112

> Vargas-Yañez M, Salat J, Luz Fernández de Puelles M, López-Jurado JL and others (2005) Trends and time variability in the Northern continental shelf of the western

Editorial responsibility: Hugh Ducklow,

Woods Hole, Massachusetts, USA
Mediterranean. J Geophys Res 110:1-18, doi:10.1029/ 2004JC002799

Vázquez-Domínguez E, Peters F, Gasol JM, Vaqué D (1999) Measuring the grazing losses of picoplankton: methodological improvements in the use of fluorescently labeled tracers combined with flow cytometry. Aquat Microb Ecol 20:119-128

- Vázquez-Domínguez E, Gasol JM, Agustí S, Duarte CM, Vaqué D (2005) Growth and grazing losses in the Central Atlantic Ocean. J Plankton Res 27:1055-1066

Vázquez-Domínguez E, Vaqué D, Gasol JM (2007) Ocean warming enhances respiration and carbon demand of coastal microbial plankton. Glob Change Biol 13: 1327-1334

> Verity PG (1991) Measurement and prey uptake by marine planktonic ciliates fed plastidic and aplastidic nanoplankton. Limnol Oceanogr 36:729-750

Verity PG, Langdon C (1984) Relationships between lorica volume, carbon, nitrogen, and ATP content of tintinnids in Narraganset Bay. J Plankton Res 6:859-868

Vidussi F, Mostajir B, Fouilland E, Le Floc'h E and others (2011) Effects of experimental warming and increased ultraviolet $\mathrm{B}$ radiation on the Mediterranean plankton food web. Limnol Oceanogr 56:206-218

Weisse T, Stadler P, Lindström ES, Kimmance SA, Montagnes DJS (2002) Interactive effect of temperature and food concentration on growth rate: a test case using the small freshwater ciliate Urotricha fracta. Limnol Oceanogr 47:1447-1455

> Wiltshire KH, Malzahn AM, Wirtz K, Greve W and others (2008) Resilience of North Sea phytoplankton spring bloom dynamics: an analysis of long-term data at Helgoland Roads. Limnol Oceanogr 53:1294-1302

Wohlers J, Engel A, Zöllner E, Breithaupt P and others (2009) Changes in biogenic carbon flow in response to sea surface warming. Proc Natl Acad Sci USA 106: 7067-7072

Submitted: August 1, 2011; Accepted: July 9, 2012

Proofs received from author(s): September 10, 2012 